\title{
Combined heat pump and water-power plant at Kaunas Lagoon
}

\author{
Vytautas Dagilis, Liutauras Vaitkus \\ Kaunas University of Technology, K. Donelaicio g. 73, Kaunas 44029, Lithuania
}

\begin{abstract}
Heat pump plants for district heating are one of the renewable energy technique as well as the means to make modern power grid more flexible. The combined heat pump and power plant presented in this work corresponds both of the objectives. High coefficient of performance of the heat pump and low price of the off-peak electricity of the water-power plant ensures low heat price. The reservoir of $20000 \mathrm{~m}^{3}$ is needed for hot water accumulation. Economic analysis revealed that the expected heat price is much lower when compared with the price of modern condensing boilers fuelled by wood chips. This ensures fast payback of investment.
\end{abstract}

Keywords: Heat pump; water power plant; heat accumulation.

\section{Introduction}

The dynamic of fossil fuel price last decade stimulated increased funding for research and development of new and renewable power and heat generating technologies based on wind, solar and geothermal energy. During this period the amount of articles concerning large scale heat pumps or heat pump plants for district heating increased several times. Previously heat pump plants were built mainly in low power price countries, Scandinavian, for example. Elsewhere the payback period was long and uncertain due to high investment cost for heat pump; therefore the combined heat and power plants, as a rule, serve for district heating system.

It should be noted that during last 10-15 years the fuel price increased more than the construction costs. The investment cost in heat pump plant seems less expensive recently. Furthermore, the electricity price increase is also lower when compared with the fuel price during the meant period. Electricity production without burning fossil fuel is growing. The decrease of power price is also stimulated by the wider expansion of power market operation.

Thus, today there are two factors that are stimulating the development of the large heat pump plants: relatively low cost of construction and lower electricity costs when compared with the fuel cost. The statement applies for the whole world but not only for recent Europe.

The China has plans to produce $16 \%$ of consumed energy from renewable sources by the year 2020 including also the development of large heat pump plant for district heating [1-4]. The Scandinavian countries are more ambitious: to achieve $100 \%$ renewable energy supply by 2060 . According H. Lund et al. [5] there are two possibilities to achieve this. One of them is to decrease energy demand for space heating by $75 \%$ which is not realistic. The second possibility is implementation of complex means in order to use various sources of renewable energy including, naturally, heat pump technology for district heating systems. This way is realistic even if the largest heat pump plants operate in these countries already $[2,6]$. In Norway, for example, there are coastal cities which can be conveniently heated by heat pump technology because the sea water temperature is about $6^{\circ} \mathrm{C}$ in winter.

Low potential heat of lakes, lagoons, ponds and the like can be utilized for heating purposes [7-10]. While the problem of the evaporator frosting is not investigated in the articles [2-10], the problem is relevant for heat pump plants in colder regions. The problems of the evaporator heat transfer effectiveness and reliability in case of ice formation on the surfaces are examined in the papers [11-14]. It is importantly to utilize this heat source in a most effective way because water is much better heat source comparing to ground [15]. The heat pump plants are more effective and better satisfy renewable energy specification when they utilize water like a low potential heat source [16, 17]. Economic and ecologic analysis shows that heat pump technology can be more advanced comparing even to cogeneration technology [18-20] although R. Lowe [21] does not agree with.

Corresponding author: Vytautas Dagilis. E-mail address: Vytautas.Dagilis@ktu.lt

http://dx.doi.org/10.3846/enviro.2014.257

(C) 2014 The Authors. Published by VGTU Press. This is an open-access article distributed under the terms of the Creative Commons Attribution License, which permits unrestricted use, distribution, and reproduction in any medium, provided the original author and source are credited. 


\section{Heat pump plants and power grid flexibility}

Recently the heat pump plant is analysed not only as advanced and renewable heat technology. In creation of the so called flexible power grid the important role is predicted to the plants - to secure the continual renewable power supply when the power production is more and more intermittent. In Denmark, for example, the problem of intermittent power production is highlighted ten years ago. In the year 2003 the decision was made that the strategy for the problem should be based not only on the further development of the wind power capacity, but also on the construction of large heat pump plants in order to increase the power grid flexibility [22].

P. Luickx et al. [23] analyse a huge heat pump system in the European region with highest population for compensation of intermittent of power generation and for power system flexibility. Moreover, the case of direct resistant heating and heat accumulation are analysed in the papers [23,24]. The idea of heat accumulation (like in the case of heat pump) is to utilize the off-peak generated electric power, mainly during the night time, for the heating purpose during a daytime. Naturally, a large volume hot water reservoir must be built for such a heating system.

It is important today that the large electricity system should contain more options for increasing the power grid flexibility. The final aim is to achieve the continual supply of renewable energy while the generation of it is intermittent. According to M.B. Blark and H. Lund [22] the flexibility may be increased by introducing storage and relocation options such as electrical energy storage facilities, pumped hydro storage, compressed air energy storage and biomass gasification, electrolytic hydrogen system with oxygen recovery and re-utilization [25], integrating heat pump system with combined heat pump and power plant $[19,20,26]$, etc. The availability of a heat pump enables the operators to use electricity for heat production rather than producing electricity due to heat production or heat production due to fuel burning. Moreover, the option for producing heat to thermal storage results in relocation of electricity avoiding the long distances transmission of power.

Lithuania is becoming part of overall European power grid and will have to take part in creation of so called SmartGrid and SuperGrid [24] for integrating intermittent renewable energies. There are exceptional possibilities to do that and, at the same time, to decrease the heat price for consumers. For example, geothermal heat capacity of Kaunas lagoon is over $2000 \mathrm{MW}$ that is more than enough for the purposes of heating the city using the heat pump system. Integrating of the system with water-power plant already operating at the lagoon offers a possibility to get very attractive heat price for Kaunas citizens. The utilization of off-peak electricity generated at the water-power plant ensures the low heat cost. It also decreases workload of power grid, which is important as well.

\section{Energetic possibilities for Kaunas lagoon heat pump}

The Kaunas water-power station sells the produced electricity at a market price. The price varies during 24 hours with average price about $160 \mathrm{LTL} / \mathrm{MWh}$. However, the off-peak electricity price is much lower and do not exceed $120 \mathrm{LTL} / \mathrm{MWh}$. The price diagram of the typical winter day is presented in Figure 1. Average electricity price per $24 \mathrm{hrs}$ is just $160 \mathrm{LTL} / \mathrm{MWh}$, and only $113,6 \mathrm{LTL} / \mathrm{MWh}$ from $21 \mathrm{~h}$ to $5 \mathrm{~h}$. This price is lower when compared with the heat price which the heat distributer "Kauno Energija" paid to the main heat producer "Kauno Elektrine" last year and also a bit higher than the price gained by fuelling wood chips. The heat production by direct resistant heating requires a large reservoir for hot water as well as some additional expenses; the obtained price would be higher when compared with the today level and, therefore, not competitive.

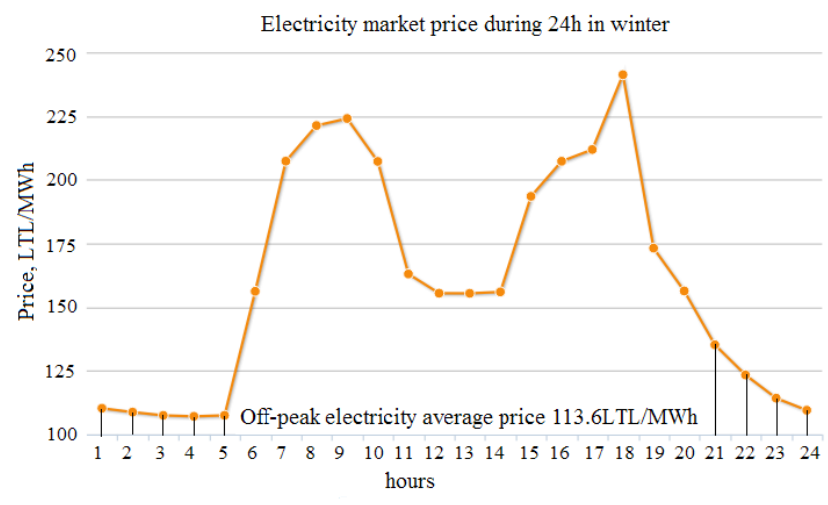

Fig. 1. Electricity price diagram during typical winter day in Lithuania

The heat pump option is much more attractive because of relatively high coefficient of performance (COP). Due to the fact that Kaunas Lagoon area is 65 million $\mathrm{m}^{2}$ with over $2000 \mathrm{MW}$ of geothermal energy, the water temperature is plus one grad at least (Fig. 2). The flow rate of the water is $160 \mathrm{~m}^{3} / \mathrm{s}$ in winter season. So $670 \mathrm{MW}$ of low potential heat can be received before water begins to freeze up. The present average heat demand of Kaunas is $250 \mathrm{MW}$, however the decrease of 
population together with prospective renovation of flat blocks should decrease the heat demand. Furthermore, there are some companies which have invested (with ES contribution) in renewable heat boilers of substantial capacity. So, the average heat capacity of $100 \mathrm{MW}$ during 24 hours with nominal $267 \mathrm{MW}$ heat capacity heat pump could be required here. However, for operation of such a large heat pump the $73 \mathrm{MW}$ of power is needed, which about twice exceeds the potential of existing water power station in winter.

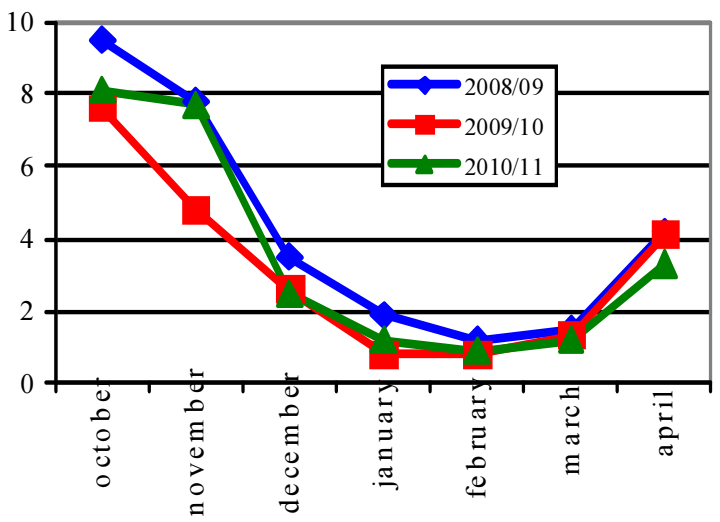

Fig. 2. Kaunas Lagoon water temperature during 2008-2011 winters

Capacity of max $40 \mathrm{MW}$ off-peak electricity can be utilized for the heat pump of $146 \mathrm{MW}$ nominal heat capacity. This is capacity of the high pressure heat exchanger (condenser) of the heat pump also. The condenser is a complex heat exchanger, which extracts only $53 \%$ of heat from the condensing vapour. The remaining $28 \%$ of heat is received from the superheated vapour and 19\% from subcooled liquid refrigerant (Fig. 3). Coefficient of performance (COP) of the heat pump is 3.65 at the lowest water temperature $+1{ }^{\circ} \mathrm{C}$ (Fig. 4). Heat capacity of the heat pump evaporator (HPE) and additional heat exchanger (AHE) are 84.0MW and 22.0MW respectively.

Area of all heat exchangers is calculated because the area (but not capacity) is determining factor for cost estimation. The cost of superheater part of the high pressure heat exchanger (HPHE) (see Fig.3) is higher comparing to the cost of condenser part. The heat transfer area of the superheater is larger although its heat capacity is smaller. The same is true when the liquid heater is compared with the additional heat exchanger (values are shown in Table 1). This is because these two lowefficiency heat transfer heat exchangers (superheater and additional heat exchanger) are used in the heat pump system. The overall heat transfer coefficient of the additional heat exchanger as well as superheater part of the high pressure exchanger is several times lower when compared to other heat exchangers. The additional expenses for these two exchangers are welljustified economically, because the higher COP of heat pump may be achieved. The condensing temperature of working fluid is lower than temperature of leaving water by 3 grad $\left(72{ }^{\circ} \mathrm{C}\right.$ versus $75^{\circ} \mathrm{C}$, Fig. 3), contrary to the case of the conventional heat pump systems. Such setup of heat pump system enables heat production with higher efficiency, especially when modern screw compressors are used instead of centrifugal or axial.

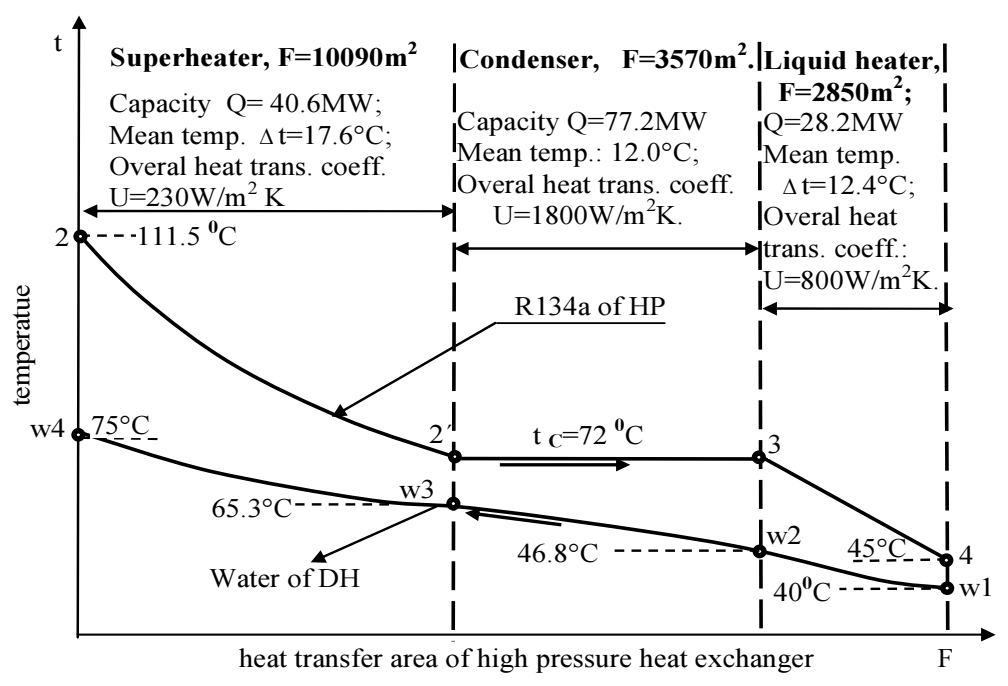

Fig. 3. The heat exchange scheme of high pressure exchanger (condenser) of HP 


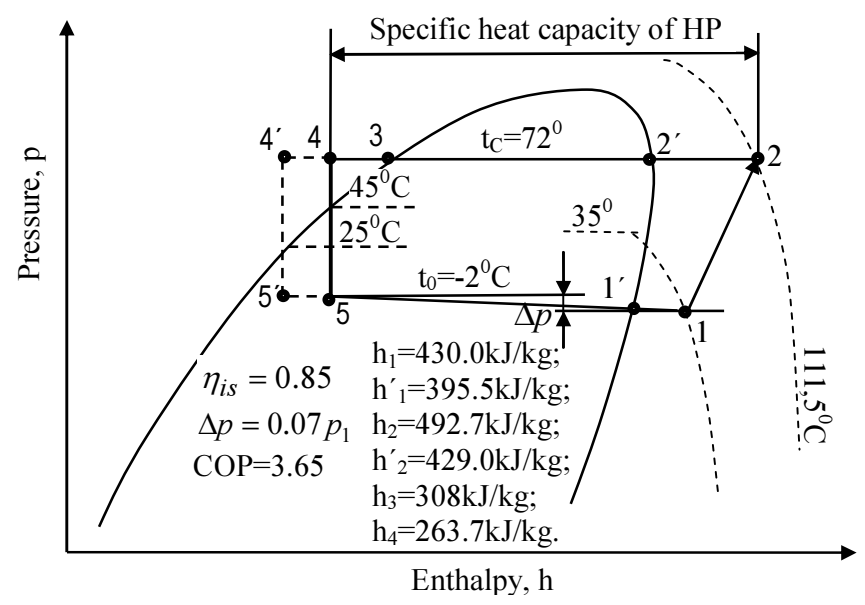

Fig. 4. The p-h diagram for heat pump cycle

Another factor related to heat transfer area of the heat exchangers is mean temperature difference of fluids. Water's intermediate temperatures $\mathrm{t}_{\mathrm{w} 3}$ and $\mathrm{t}_{\mathrm{w} 2}$ in high pressure heat exchanger are calculated according to relations of proportion:

$$
t_{w 2}=t_{w 1}+\frac{h_{3}-h_{4}}{h_{2}-h_{4}}\left(t_{w 4}-t_{w 1}\right) ; \quad t_{w 3}=t_{w 4}-\frac{h_{2}-h_{2}^{\prime}}{h_{2}-h_{4}}\left(t_{w 4}-t_{w 1}\right)
$$

Table 1. Characteristics of heat exchangers

\begin{tabular}{|l|l|l|l|l|}
\hline & $\begin{array}{l}\text { Capacity } \\
\text { MW }\end{array}$ & $\begin{array}{l}\text { Mean temperature } \\
\text { difference, K }\end{array}$ & $\begin{array}{l}\text { Heat transf. coeff. } \\
\text { W/m } \mathrm{m}^{2} \mathrm{~K}\end{array}$ & $\begin{array}{l}\text { Heat transf. area } \\
\mathrm{m}^{2}\end{array}$ \\
\hline Evaporator & 84.0 & 3.5 & 1500 & 16000 \\
\hline AHE & 22.0 & 28.1 & 130 & 6020 \\
\hline Superheater & 40.6 & 17.6 & 230 & 10090 \\
\hline Condenser & 77.2 & 12.0 & 1800 & 3570 \\
\hline Liquid heater & 28.2 & 12.4 & 800 & 2850 \\
\hline
\end{tabular}

Calculated mean temperature differences of this heat exchanger are shown in Fig. 3. All characteristics of heat exchangers, including heat transfer area for economic analysis, are presented in Table 1.

\section{Economic analysis of the plant}

The scheme of combined heat pump and water-power plant at Kaunas lagoon is presented in Figure 5. Water after hydro turbine (HT), which turns electro generator $(\mathrm{G})$, passes the heat pump evaporator (HPE). The evaporator uses low temperature water heat for evaporation of the working fluid (R134a). Water temperature decreases from $1{ }^{\circ} \mathrm{C}$ to $0.88{ }^{\circ} \mathrm{C}$ cooling all flow of the river. The HP utilizes off-peak electricity produced in the water-power station (40 MW) and produces 1.31 million $\mathrm{kWh}$ of heat energy during 9 hours. The heat storage reservoir of 20000 cubic meters is needed for heat accumulation. Height of the reservoir is 16 meters so water stratification by temperature is enough for keeping temperature difference of $35^{\circ} \mathrm{C}$. Thermal isolation of the reservoir has to ensure thermal resistance $6 \mathrm{~m}^{2} \mathrm{~K} / \mathrm{W}$ and heat loses less than $0.1 \%$. The rel. price of the Vilnius oil reservoir is 0.33 million LTL/1000 $\mathrm{m}^{3}$ so the investigation cost of the hot water reservoir without isolation should be 6.7 million LTL. For insulation 800 cubic meters of polystyrene blocks is needed that increases the final construction up to 7.3 million LTL.

Hot water for district heating have to pass $2 \mathrm{~km}$ distance to Petrošiūnai heat and power station therefore the heat network connection must be built as well as the electrical power line in case power capacity of the water-power station is insufficient.

The reservoir and heat pump evaporator would be most expensive devices of the project. The evaporator of 16 thousand $\mathrm{m}^{2}$ must be constructed from copper tubes in order to resist corrosion. The evaporator will require 110 tons of copper tubes with 4.6 million LTL bill of materials for metal alone. Additional construction cost of HPE is estimated as $20 \%$ and cost for installation - as 60\% [27] (3.5 million LTL) making overall 8.8 million LTL.

According to [28] the heat pump compressor would cost 1.9 million USD (4.8 million LTL). A. Arsalis [28] offers relations for the heat exchangers costs calculation as well. Authors of the article [30-31] propose other relationship for the cost of heat exchanger with quite different expression. However the calculated results by both relationships are close enough (see Table 2). 


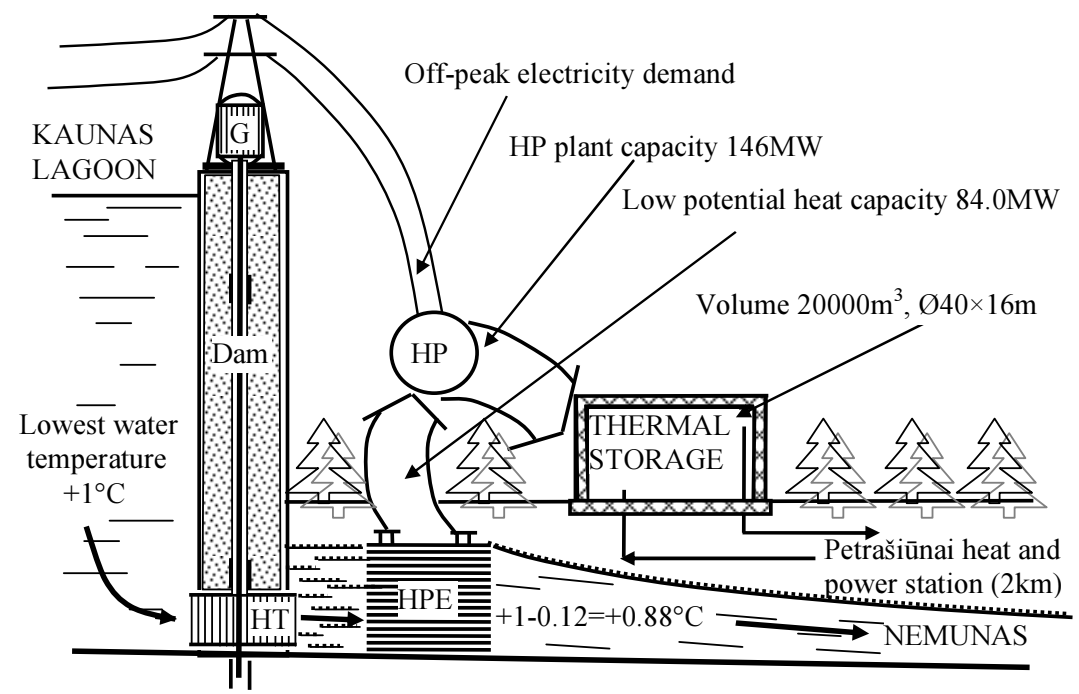

Fig. 5. Scheme of combined heat pump and water-power plant at Kaunas lagoon

All the expenses including costs of planning, building and constructing, improvements to site, balance as well as owner's costs are taken from [31], which proposes cost of different power generation technologies. Compressed air energy storage power plant is more closed to the plant presented in this article. All the expenses of the new combined heat pump and water power plant are shown in the Table 2 .

Table 2. Expenses of combined heat pump and water power plant

\begin{tabular}{l|l|l|l|l}
\hline Component & Characteristic & $\begin{array}{l}\text { Cost by author [28] } \\
\text { mill. USD/mill. LTL }\end{array}$ & $\begin{array}{l}\text { Cost by authors [30] } \\
\text { mill. USD/mill. LTL }\end{array}$ & $\begin{array}{l}\text { Taken cost } \\
\text { mill. LTL }\end{array}$ \\
\hline Superheater of the HPHE & $10090 \mathrm{~m}^{2}$ & $1.1 / 2.9$ & $1.1 / 2.7$ & 2.8 \\
\hline Condenser of the HPHE & $3570 \mathrm{~m}^{2}$ & $0.49 / 1.3$ & $0.44 / 1.1$ & 1.2 \\
\hline Liquid heater of the HPHE & $2850 \mathrm{~m}^{2}$ & $0.41 / 1.1$ & $0.4 / 0.9$ & 1.0 \\
\hline Additional heat exchanger & $6020 \mathrm{~m}^{2}$ & $0.74 / 1.9$ & $0.68 / 1.76$ & 1.8 \\
\hline Evaporator (cupper) & $16000 \mathrm{~m}^{2}$ & & & 8.8 \\
\hline Reservoir for heat storage & $20000 \mathrm{~m}^{3}$ & & 7.3 \\
\hline $\begin{array}{l}\text { Engineering, procurement, } \\
\text { Construction management service }\end{array}$ & $360 \mathrm{USD} / \mathrm{kW}$ POWER & & & 37.4 \\
\hline Balance of the plant & $50 \mathrm{USD} / \mathrm{kW}$ POWER & & & 5.2 \\
\hline Owner's costs & $60 \mathrm{USD} / \mathrm{kW}$ POWER & & & 6.2 \\
\hline All costs & & & & 71.7 \\
\hline
\end{tabular}

The payback rate depends on two factors. The first factor is the heat cost difference between the cost attained by the modern condensing boilers on the one hand, and the heat cost of the discussed plant on another, at the time of common operation of both heat producers. The second factor is related with the financial support to the project (like ecological funds). Obviously, the combined heat pump and water-power plant produces heat without any emission of $\mathrm{CO} 2$ meanwhile the meant condensing boilers have to use oil fuel for wood chips preparation, transportation as well as expend electricity in the heat plant for blowers, chips feeding, etc. It would be pilot project, which should be supported because it is concerned with the development of progressive district heating.

The present bio-fuel heat cost is about $0.1 \mathrm{LTL} / \mathrm{kWh}$ and should be higher by $10 \%$ in next few years. The estimated heat cost of presented plant is much lower. Each $\mathrm{kWh}$ of mechanical energy produces $3.65 \mathrm{kWh}$ of heat. The efficiency of the electric motor should be $97 \%$, so each $\mathrm{kWh}$ of electricity produces $3.54 \mathrm{kWh}$ of heat energy suitable for district heating system at average temperature of the heating season in Kaunas. Hence, the fraction of cost for electricity is only $0.032 \mathrm{LTL} / \mathrm{kWh}$. The operation and maintain cost of the plant is lower as well and make only $0.002 \mathrm{LTL} / \mathrm{kWh}[29]$. The difference comparing to the heat costs is $0.066 \mathrm{LTL} / \mathrm{kWh}$, which makes the income difference of 28.9 million LTL per year (it is assumed that the plant produces heat for district heating with the average capacity of $55 \mathrm{MW}$ and for hot water preparation in summer with the average capacity of $45 \mathrm{MW}$ ). All the amount of income difference can be directed for capital return. The payback period including plant construction time is 5.2 years (Fig. 6). 


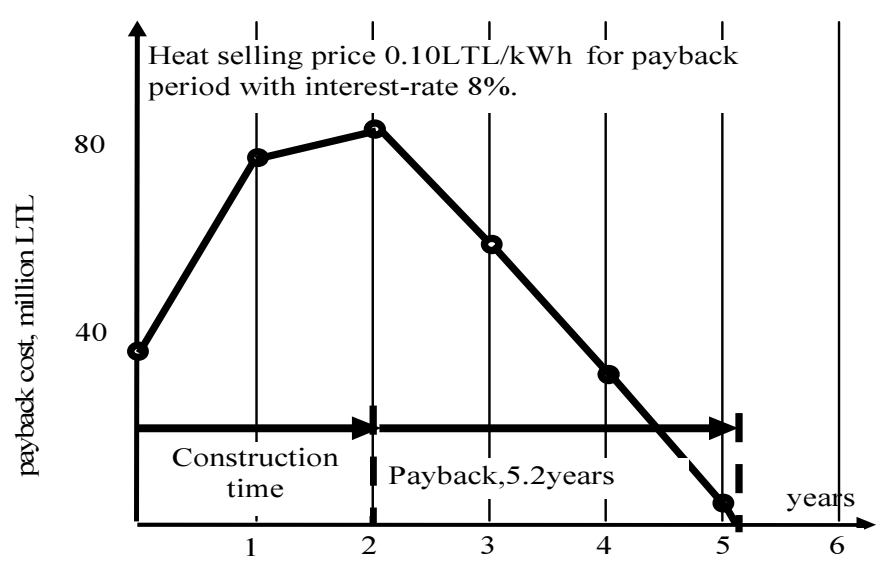

Fig. 6. Dynamic of payback costs during construction and payback

Heat price components and final price for Kaunas consumers after payback period are:

- energy (electricity) cost $-0.032 \mathrm{LTL} / \mathrm{kWh}$;

- operation and maintain $-0.002 \mathrm{LTL} / \mathrm{kWh}$;

- depreciation $-0.006 \mathrm{LTL} / \mathrm{kWh}$;

- profit - $0.005 \mathrm{LTL} / \mathrm{kWh}$;

- distribution - $0.05 \mathrm{LTL} / \mathrm{kWh}$;

- the price with taxation $-(9 \%) 0.095 \times 0.09=0.104 \mathrm{LTL} / \mathrm{kWh}$.

\section{Conclusions}

The combined heat pump and water-power plant is presented in the paper. The two main factors enable exceptional low heat cost of the plant: relatively high COP of the heat pump and low price of electricity. Comparatively high temperature of the low potential heat source, exclusively effective heat transfer of the evaporator and the fact that $28 \%$ of heat is getting from superheated gas determine high COP value 3.65. The low price of electricity is ensured by utilization of only off-peak electricity produced by water-power station. The reservoir of $20000 \mathrm{~m}^{3}$ is needed for hot water accumulation. Economic analysis revealed that the expected heat price is much lower when compared with the price of modern condensing boilers fuelled by wood chips which ensures fast payback of investment. The final heat price after the payback is $0.104 \mathrm{LTL} / \mathrm{kWh}$ including $9 \%$ of value-added tax.

\section{References}

[1] Zhen, L.; Duanmu, L. 2005. Natural conditions assessment of using seawater resource heat pump in Dalian, in The 4th international conference on sustainable energy technologies, Jinan, China, 493-496.

[2] Zhen, L.; Lin, D. M.; Shu, H. W.; Shuang, J.; Zhu,Y. X. 2007. Distric cooling and heating with seawater as heat source and sink, in Renewable Energy 32: Dalian, China, 2603-2616.

[3] Ministry of Water Resources of PR China, 2002.Water Resources Bulletin, the People's Republic of China Beijing, China, 2003. Available from Internet: http://www.mwr.gov.cn/english

[4] Chen, X.; Zhang, G.; Peng, J.; Lin, X.; Liu, T. The performance of an open-lop lake water heat pump system in south China, Appl. Therm. Eng. 26: 2255-2261. http://dx.doi.org/10.1016/j.applthermaleng.2006.03.009

[5] Lund, H.; Moller, B.; Mathiesen, B.V.; Dyrelund, A. 2010. The role of district heating in future renewable energy systems, Energy 35: 1381-1390. http://dx.doi.org/10.1016/j.energy.2009.11.023

[6] Oslo-Fornebu: sustainable development with a district heating/cooling system using the high efficiency of the UnitopR 28/22CY, Available from Internet: http://www.axiref.com/internet/refch/en/home/referenzenfernwaerme_fernkaelte.MultipleMultiContList.0005.file.pdf

[7] Aittomaki, A. 2003. Lakes as a heat source in cold climate, in Proceedings of International Congress of Refrigeration, Washington, USA, 2003.

[8] Kavanaugh, S. P.; Pezent, M. C. 1990. Lake water applications of water-to-air heat pumps, ASHRAE Transactions Part I 96: 813-820.

[9] Buyukalaca, O.; Ekinci, F.; Yilmaz, T. 2003. Experimental investigation of Seyhan River and dam lake as heat source-sink for a heat pump, Energy 28: 157-169. http://dx.doi.org/10.1016/S0360-5442(02)00088-9

[10] Tim, P.; Joyce, W. S. 2002. Lake-source cooling, ASHRAE Journal 44 (4): 37-39.

[11] Hirata, T.; Matsui, H. 1990. Ice formation and heat transfer with water flow around isothermally cooled cylindres arranged in a line, $A S M E J$. Heat Transfer 112: 707-713. http://dx.doi.org/10.1115/1.2910444

[12] Torikoshi, K.; Nakazawa, Y.; Ymashita, H. 1990. Experimental study of formation and melting of ice around horizontal tubers 143: 57-63.

[13] Intemann, P. A.; Kazmierczak, M. 1997. Heat transfer and ice formation deposited upon cold tube bundles immersed in flowing water - I. Convection analysis, Int. J. Heat Transfer 40: 557-572. http://dx.doi.org/10.1016/0017-9310(96)00121-4

[14] Kazmierczak, M.; Intemann, P. A. 1997. Heat transfer and ice formation deposited upon cold tube bundles immersed in flowing water - II. Conjugate analysis, Int. J. Heat Transfer. 40: 573-588. http://dx.doi.org/10.1016/0017-9310(96)00122-6

[15] Rybach, L.; Eugster, W. J. 2002. Sustainability aspects of geothermal heat pumps, in Proceedings, 27-th Workshop on Geothermal Reservoir Engineering Stanfort University, California, 28-30.

[16] Blarke, M.; Lund, H. 2007. Large-scale heat pumps in sustainable energy systems:system and project perspectives, Thermal Science 11(3): 141-152. http://dx.doi.org/10.2298/TSCI0703143B 
[17 IEA, 1992. Heat Pumps, an Opportunity for Reducing the Greenhouse Effect, IEA Heat Pump Centre, The Netherlands.

[18] Curti, V.; von Spakovsky, M. R.; Favrat, D. 2000. An environomic approach for the modeling and optimization of a district heating network based on centralized and decentralized heat pumps, cogeneration and gas furnace (part I and part II), Int. J.Therm. Sci. 39(7): 721-741. $\mathrm{http}: / /$ dx.doi.org/10.1016/S1290-0729(00)00226-X

[19] Dagilis,V. 2013. Combined heat pump and power plant. Part I: thermodynamic analysis, Mechanika 19(1): 19-24.

[20] Dagilis, V. 2013. Combined heat pump and power plant. Part II: economic analysis, Mechanika 19(2): 172-177. http://dx.doi.org/10.1016/j.enpol.2011.05.007

[21] Lowe, R. 2011. Combined heat and power considered as a virtual steam cycle heat pump, Energy Policy 39: 5528-5534

[22] Blark, M. B.; Lund, H. 2008. The effectiveness of storage and relocation options in renewable energy systems, Renewable Energy 33: $1499-1507$. http://dx.doi.org/10.1016/j.renene.2007.09.001

[23] Luickx, P.; Helsen, L.; D'haeseleer, W. 2008. Influence of massive heat-pump introduction on the electricity-generation mix and the GHG effect: Comparison between Belgium, France, Germany and The Netherlands, Renewable and Sustainable Energy Reviews 12(8): 2140-2158.

[24] Blark, M. B.; Jenkins, B. M. 2013. Supper Grid or Smart Grid: Competing strategies for large-scale integration of intermittent renewables?, Energy Policy 58: 381-390. http://dx.doi.org/10.1016/j.enpol.2013.03.039

[25] Agbossou, K.; Kolhe, M. L.; Hamelin, J.; Bernier, E.; Bosse, T. K. 2004. Electrolytic hydrogen based renewable energy system with oxygen recovery and re-utilization, Renew Energy 29: 1305-1318. http://dx.doi.org/10.1016/j.renene.2003.12.006

[26] Lazzarin, R.; Noro, M. 2006. District heating and gas engine heat pump Economic analysis based on a case study, Applied Thermal Engineering 26(23): 193-199. http://dx.doi.org/10.1016/j.applthermaleng.2005.05.013

[27] Burer, M.; Tanaka, K.; Favrat, D.; Yamada, K. 2003. Multi-criteria optimization of a district cogeneration plant integrating a solid oxide fuel cell-gas turbine combined cycle, heat pumps and chilers, Energy 28: 497-518. http://dx.doi.org/10.1016/S0360-5442(02)00161-5

[28] Arsalis, A. 2008. Thermoeconomic modeling and parametric study of hybrid SOFC-gas turbine-steam turbine power plants ranking from 1.5 to 10MWE.

[29] Dagilis, V. 2011. Kaunas heat pump plant or how to reduce heat price twice, Energijos Erdve 4(11): 19-23.

[30] Sayyaadi, H.; Mehrabipour, R. 2012. Efficiency enhancement of a gas turbine cycle using an optimized turbular recuperative heat exchanger, Energy 38: 362-375. http://dx.doi.org/10.1016/j.energy.2011.11.048

[31] National Renewable Energy Laboratory (NREL) (2012). Cost and performance data for power generation technologies. Blach \&Veatch Holding Company, 105p. 